\title{
ANALISIS ABUTMENT JEMBATAN SEI. BUSUK KABUPATEN SIAK SRI INDRAPURA PROVINSI RIAU
}

\author{
Muhammad Yasin \\ Program Studi Teknik Sipil Universitas Lancang Kuning \\ Jalan Yos Sudarso Km. 8 Rumbai Pekanbaru \\ E-mail : yasin_muhammad12@yahoo.com \\ Gusneli Yanti \\ Program Studi Teknik Sipil Universitas Lancang Kuning \\ Jalan Yos Sudarso Km. 8 Rumbai Pekanbaru \\ E-mail :gusneli@unilak.ac.id \\ Shanti Wahyuni Megasari \\ Program Studi Teknik Sipil Universitas Lancang Kuning \\ Jalan Yos Sudarso Km. 8 Rumbai Pekanbaru \\ E-mail : $\underline{\text { shanti@unilak.ac.id }}$
}

\begin{abstract}
Abstrak
Sesuai dengan Perpres 58/2017 No.232 tentang penetapan Tanjung Buton sebagai kawasan industri yang merupakan proyek strategis nasional, Pemerintah Pusat melalui Kementrian Pekerjaan Umum, BBPJN II Medan, Satuan Kerja Pelaksanaan Nasional Wil.II Provinsi Riau melakukan pembangunan jembatan dan jalan agar transportasi menjadi lancar. Rencana pembangunan jembatan ini terletak di Kabupaten Siak Sri Indrapura Provinsi Riau tepatnya pada STA 116+050 ruas jalan Siak Sri Indrapura - Mengkapan/Buton yang merupakan jalan penghubung menuju kawasan industri Pelabuhan Buton. Semula Pembangunan jembatan ini merupakan proyek untuk mengganti jembatan lama yang tidak sesuai dengan standar jalan nasional, namun karena masalah keselamatan dan keamanan kerja maka pembangunan nya dipindah ke sisi kiri jalan menuju kawasan industri Tanjung Buton. Penelitian ini bertujuan untuk mengetahui stabilitas Abutment Jembatan dan analisis dilakukan berdasarkan Standard Penetration Test (SPT) dan data tanah berdasarkan hasil dari laboratorium. Berdasarkan hasil analisis dari data yang diperoleh bahwa Abutment aman sehingga tidak akan mengalami guling, pergeseran dan keruntuhan daya dukung tanah. Stabilitas terhadap guling 2,75>1,5 dan stabilitas terhadap geser 2,64>1,5 serta stabilitas terhadap keruntuhan kapsitas dukung tanah 7,74>3 maka desain perencanaan awal untuk bangunan abutment dapat dipergunakan.
\end{abstract}

Kata Kunci : Abutment, Jembatan, Stabilitas 


\begin{abstract}
Base on Perpres 58/2017 No.232 concerning the establishment of Tanjung Buton as an industrial area which is a national strategic project, the central government through the Ministry of Public Works, BBPJN II Medan, Riau Province II National Implementation Work Unit are going to construct bridges and roads, so that transportation runs well. The construction plan of this bridge is located in Siak Sri Indrapura Regency, Riau Province, precisely at STA 116 + 050 Siak Sri Indrapura - Mengkap / Buton road which is a connecting road to the Buton Port industrial area. At the first time the construction of the bridge was a replaced project for the old one which was not suitable to national road standards, nevertheless due to work safety and security, the construction was moved to the left side of the road to the Tanjung Buton industrial area. This study aims to determine the stability of Bridge Abutment and the analysis is done based on the Standard Penetration Test (SPT) and the soil data is based on laboratory result. According to the analysis of the data result, Abutment is well done/ safe so that rolling, shifting and collapse of the carrying capacity will not happened. The stabilities as follow rolling is 2,75>1,5 shifting is 2,64>1,5 and collapse of carrying of soil capacity is 7,74>3. Therefore, early planning design for abutment construction can be applied.
\end{abstract}

Keywords: Abutment, Bridges, Stability

\section{A. PENDAHULUAN}

Jalan sebagai salah satu prasarana transportasi, mempunyai peranan yang penting di dalam kelancaran transportasi untuk pemenuhan hidup. Sehingga jalan yang lancar, aman dan nyaman telah menjadi kebutuhan hidup utama. Dengan meningkatnya jumlah penduduk, pertumbuhan ekonomi yang cukup tinggi serta didukung oleh potensi daerah yang cukup baik menyebabkan arus lalu lintas pada jalur tersebut akan semakin ramai.

Untuk menampung kepasitas dan beban lalu lintas yang lebih besar maka dibuat perencanaan jembatan baru yang lebih kuat. Dimana existing jembatan lama memiliki lebar 5 meter, panjang 13 meter dengan jenis jembatan adalah komposit (Ex.Chevron). Sedangkan rencana jembatan baru yang akan dibuat memiliki lebar 7,6 meter, panjang 25 meter dengan jenis jembatan adalah beton prategang.
Alasan lain yang melandasi perlunya pembangunan jembatan ini adalah dengan ditetapkannya Tanjung Buton sebagai kawasan industri yang merupakan proyek strategis nasional (Perpres 58/2017 No.232). Untuk mendukung Perpres tersebut maka pemerintah pusat melalui Kementrian Pekerjaan Umum, BBPJN II Medan, Satuan Kerja Pelaksanaan Nasional Wil.II Provinsi Riau, agar transportasi menjadi lancar. Rencana pembangunan jembatan ini terletak di Kabupaten Siak Sri Indrapura Provinsi Riau tepatnya pada STA 116+050 ruas jalan Siak Sri Indrapura - Mengkapan/Buton yang merupakan jalan penghubung menuju kawasan industri Pelabuhan Buton.

Berdasarkan surat dari PT. Bumi Siak Pusako - Pertamina Hulu No. 218/GM/IV/2018 tanggal 13 April 2018 bahwa pengerjaan penggantian jembatan Sei. Busuk berada di area merah bersinggungan dengan powerline high voltage milik BOB PT. BSP - Pertamina 
Hulu sehingga dari sisi keselamatan dan keamanan pekerjaan tersebut tidak dapat dilaksanakan, dan mengusulkan agar membuat jalur dan jembatan baru di seberang powerline high voltage milik mereka. Rencana relokasi dapat dilihat pada gambar 1

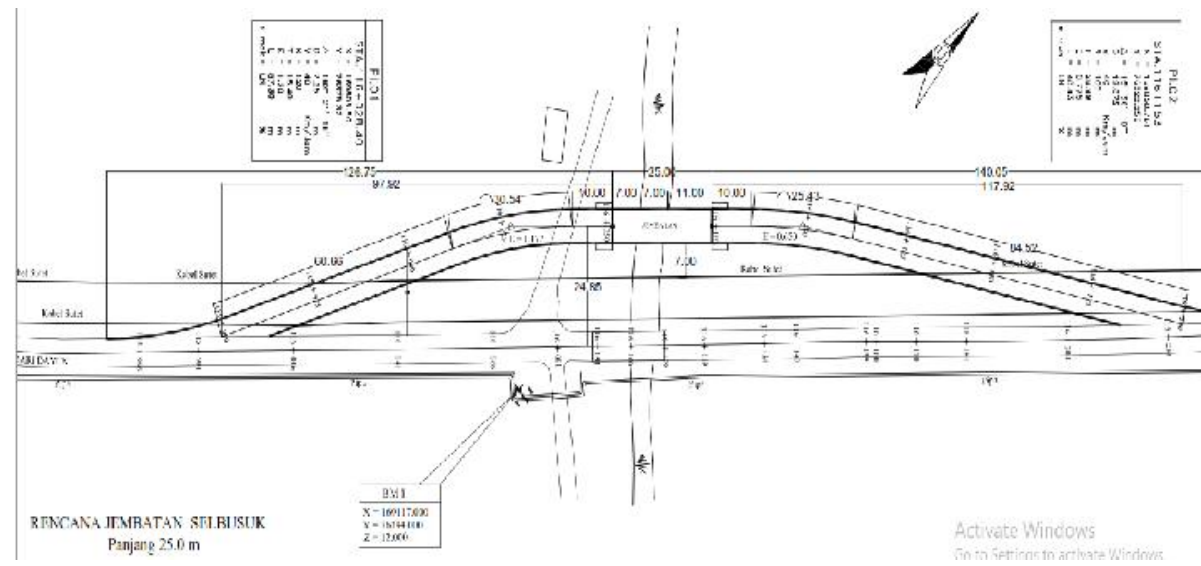

Gambar 1 Relokasi Jembatan

(Sumber : Dokumentasi Lapangan, 2018)

Penelitian terdahulu tentang daya dukung tanah yang mampu memikul dan memberikan keamanan (Chandra, 2018) perhitungan yang digunakan untuk analisis daya dukung pondasi bored pile menggunakan data sondir diantaranya yaitu Metode Aoki dan De Alencar, Metode Schmertmann dan Nottingham, Metode Meyerhoff, dan Metode Guy Sangrelatt. Sedangkan Husnah H (2015) menghitung daya dukung berdasarkan data sondir dan SPT dengan beberapa metode untuk data sondir dengan menggunakan metode Aoki De Alencar dan metode langsung sedangkan untuk data SPT menggunakan metode Mayerhof dan untuk penurunan tiang tunggal dihitung menggunakan metode Poulus dan Davis.

\section{B. TINJAUAN PUSTAKA}

\section{Pengertian Jembatan}

Jembatan adalah suatu bangunan yang memungkinkan suatu jalan menyilang sungai/saluran air, lembah atau menyilang jalan lain yang tidak sama tinggi permukaannya. Dalam perencanaan dan perancangan jembatan sebaiknya mempertimbangkan fungsi kebutuhan transportasi, persyaratan teknis dan estetika-arsitektural yang meliputi: aspek lalu lintas, aspek teknis, aspek estetika (Supriyadi dan Muntohar, 2007).

Jembatan dapat didefinisikan sebagai suatu konstruksi atau struktur bangunan yang menghubungkan rute atau lintasan transportasi yang terpisah baik oleh sungai, rawa, danau, selat, saluran, jalan raya, jalan kereta api, dan perlintasan lainnya (Manu, 1995).

Menurut (Manu, 1995) Secara garis besar konstruksi jembatan terdiri dari dua komponen utama yaitu bangunan atas (super structure/upper structure) dan bangunan bawah (sub structure). Bangunan atas merupakan bagian jembatan yang menerima langsung beban dari orang dan kendaraan yang melewatinya.

Bangunan atas terdiri dari komponen utama yaitu lantai jembatan, rangka utama, gelagar melintang, gelagar memanjang, diafragma, 
pertambatan, dan perletakan. Selain itu juga terdapat komponen penunjang yaitu perlengkapan sambungan, ralling, pagar jembatan, drainase, dan penerangan.

\section{Bangunan Atas (upper structure)}

Bangunan atas merupakan bagian atas suatu jembatan yang berfungsi untuk menampung bebanbeban yang ditimbulkan oleh lalu lintas, orang, atau lainnya, yang kemudian menyalurkannya kebangunan di bawahnya.

\section{Bangunan Bawah (sub structure)}

Struktur bawah jembatan meliputi: pangkal jembatan (Abutment) dan pondasi. Gaya yang bekerja pada abutment jembatan terdiri dari gaya vertikal dan gaya horizontal seperti terlihat pada gambar 2

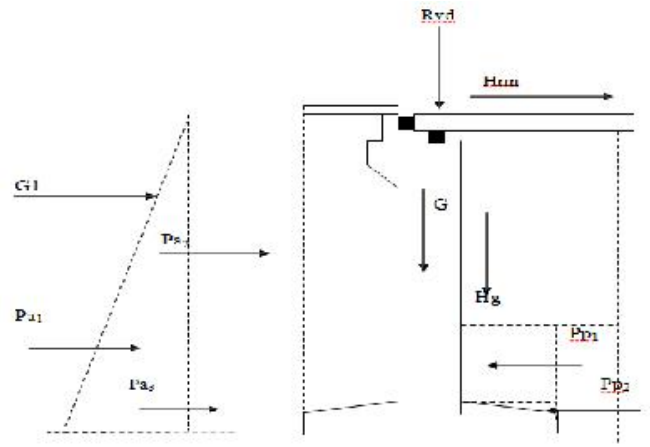

Gambar 2 Gaya-gaya yang bekerja pada abutment

(Sumber: Supriadi, B., \& Muntohar, A. S., 2007)

Keterangan:

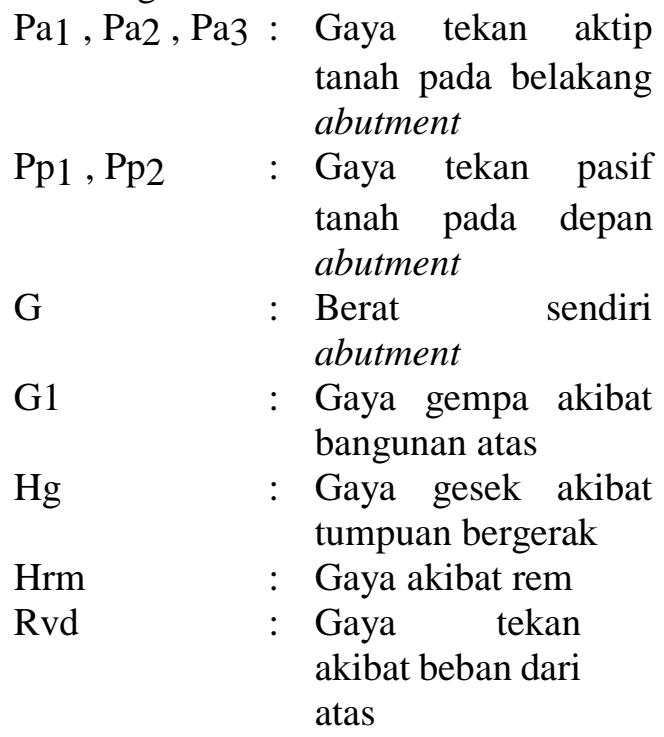

\section{Kapasitas Dukung Tiang}

Menurut Hardiyatmo C.H. (2017) tanah harus mampu menopang beban dari setiap konstruksi yang direncanakan yang ditempatkan di atas tanah tersebut. Perhitungan kapasitas dukung tanah sangat bergantung pada karakteristik tanah yang parameternya dapat ditentukan dari hasil uji triaksial maupun hasil pengujian geser langsung. Dan parameter yang sangat berpengaruh adalah $\emptyset$ dan C. Sedangkan batasan mengenai nilai $\emptyset$, dilihat pada tabel 1 .

Tabel 1 Rentang nilai sudut geser

\begin{tabular}{lc}
\hline \multicolumn{1}{c}{ Jenis tanah } & sudut geser \\
\hline Pasir lepas & $27-35$ \\
Pasir sedang & $30-40$ \\
Pasir padat & $35-45$ \\
Lempung berpasir & $34-48$ \\
Lempung & $26-35$ \\
\hline \multicolumn{2}{l}{ (Sumber: Hardiyatmo C.H, 2017) }
\end{tabular}

Untuk menghitung kapasitas dukung yang diijinkan untuk suatu tiang dapat dihitung berdasarkan data data penyelidikan tanah (soil 
investigation), cara kalender atau dengan tes pembebanan (loading test) pada tiang.

Berdasarkan data-data penyelidikan tanah kapasitas dukung tiang dapat dilakukan dengan cara:

a. Cone penetration test (CPT)

b. Standard Penetration Test (SPT)

Menurut Hardiyatmo C.H. (2017) ditinjau dari cara mendukung beban, tiang dapat dibagi 2 macam yaitu:

a. Tiang dukung ujung (End bearing Pile)

b. Tiang gesek (Friction file)

Tiang dukung ujung umumnya berada dalam zona tanah yang lunak yang didasari tanah keras. Tiang dipancang sampai batuan dasar atau lapisan keras, sehingga dapat mendukung beban yang diperkirakan dengan tidak mengakibatkan penurunan berlebihan. Kapasitas dukung tiang, sepenuhnya ditentukan dari tahanan dukung lapisan keras yang berada di bawah ujung tiang. Tahanan ujung satuan diperoleh dari gambar 3

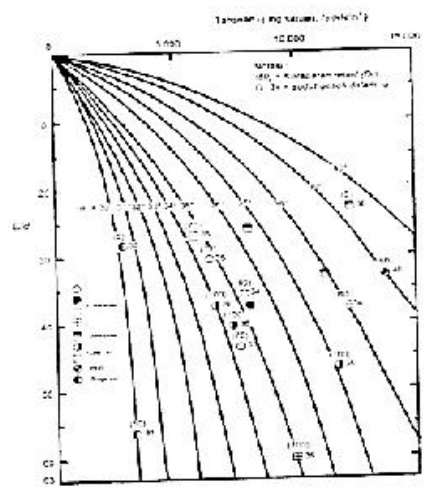

Gambar 3 Tahanan ujung satuan (Sumber: Hardiyatmo C.H, 2017)

Tiang gesek adalah tiang yang kapasitas dukungnya lebih ditentukan oleh perlawan gesek antara sisi tiang dan tanah disekitarnya. Tahanan gesek dan pengaruh konsolidasi lapisan tanah yang di bawahnya diperhitungkan pada kapasitas dukung tiang. Faktor kapasitas dukung diperoleh dari gambar 4



Gambar 4 Hubungan sudut gesek \& Nq

(Sumber: Hardiyatmo C.H, 2017)

Koefisien tekanan tanah yang bergantung pada kondisi tanah, sedangkan nilai sudut gesek tergantung pada bahan yang dipergunakan. Nilai Kd dan $\delta$ diperoleh dari tabel 2 dan tabel 3

Tabel 2 Nilai $K_{d}$

\begin{tabular}{ll}
\hline Tanah & \multicolumn{1}{c}{$\mathrm{K}_{\mathrm{d}}$} \\
\hline Pasir & $1,0-2,0$ \\
Lanau & 1,0 \\
Lempung & 1,0
\end{tabular}

(Sumber: Hardiyatmo C.H, 2017)

Tabel 3 Nilai $\delta$

\begin{tabular}{cc} 
Bahan Tiang & \\
\hline Tiang baja & $0,67 \varphi^{\prime}-0,83 \varphi^{\prime}$ \\
Tiang beton & $0,9 \varphi^{\prime}-1,00 \varphi^{\prime}$ \\
Tiang kayu & $0,8 \varphi^{\prime}-1,00 \varphi^{\prime}$ \\
\hline
\end{tabular}

(Sumber: Hardiyatmo C.H, 2017)

Bila tiang didalam tanah kohesif, Faktor adhesi $(\alpha)$ sebaiknya didasarkan pada kuat geser tanah tak terganggu, dan nilai $\mathrm{Cu}$ dapat dilihat pada gambar 5

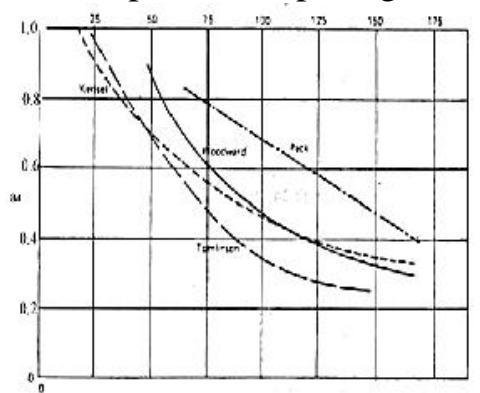

Gambar 5 Faktor adhesi tanah lempung (Sumber: Hardiyatmo C.H, 2017) 


\section{Kapasitas Dukung Kelompok Tiang}

Kapasitas kelompok tiang tidak selalu sama dengan jumlah kapasitas tiang tunggal yang berada dalam kelompoknya. Hal ini terjadi jika tiang dipancang dalam lapisan pendukung yang mudah mampat atau dipancang dalam lapisan tanah yang tidak mudah mampat, namun di bawahnya terdapat lapisan lunak. Dalam kondisi tersebut stabilitas kelompok tiang tergantung dari dua hal yaitu:

a. Kapasitas dukung tanah di sekitar dan di bawah kelompok tiang dalam mendukung beban total struktur.

b. Pengaruh penurunan konsolidasi tanah yang terletak di bawah kelompok tiang.

Untuk menghitung kapasitas tiang yang berkaitan dengan keruntuhan blok, Terzaghi dan Peck (1948) mengambil asumsi sebagai berikut:

a. Pelat penutup tiang (pile cap) sangat kaku.

b. Tanah yang berada di dalam kelompok tiang-tiang berkelakuan seperti blok padat.

\section{Stabilitas abutment}

Menurut Hardiyatmo C.H. (2017) analisis stabilitas abutment ditinjau terhadap faktor aman terhadap penggeseran dan pengulingan harus mencukupi. Untuk faktor aman terhadap penggeseran dasar abutment minimum diambil 1,5 Bowles (1997). Tekanan tanah lateral yang diakibatkan oleh tanah urug di belakang abutment, cenderung menggulingkan abutment dengan rotasi pada ujung kaki depan pelat abutment. Momen penggulingan ini, dilawan oleh momen akibat berat sendiri abutment dan momen akibat berat tanah. Untuk faktor aman terhadap penggulingan abutment minimum diambil 1,5
Tekanan tanah yang terjadi pada dasar pondasi harus tidak boleh melebihi kapasitas dukung tanah ijin. Keruntuhan abutment banyak disebabkan oleh perencanaan abutment yang kurang sempurna. Karena itu Terzaqhi dan Peck (1948) dalam Hardiyatmo C.H. (2017) menyarankan agar penyelidikan tanah dasar abutmen sampai kedalaman yang sama dengan tinggi abutment dihitung dari dasar abutment. Untuk faktor aman terhadap keruntuhan kapasitas dukung tanah minimum diambil 3

\section{METODE PENELITIAN}

\section{Lokasi Penelitian}

Penelitian dilakukan di pembangunan Jembatan Sei. Busuk Kabupaten Siak Sri Indrapura Provinsi Riau.

\section{Survey dan Pengumpulan Data}

Untuk menganalisa abutment jembatan Sei Busuk Kabupaten Siak Provinsi Riau, diperlukan sejumlah data yang didapat secara langsung yaitu dengan melakukan peninjauan langsung kelapangan (primer) ataupun data yang didapatkan dari instansi terkait ataupun literatur (skunder), serta data penujang lainnya, dengan tujuan agar dapat menarik kesimpulan dalam menentukan stabilitas abutment jembatan.

\section{Pengolahan dan Analisa Data}

Data yang dipergunakan diperoleh dari data N-SPT, Data SPT yang ada kemudian dikoreksi terhadap dua hal, meliputi:

a. Koreksi overburden

Dianggap jenis pasir sepanjang kedalaman adalah jenis pasir halus normally consolidated, sehingga persamaan koreksi overburden yang digunakan adalah:

$$
\mathrm{CN}=\frac{2}{1+\left(P O^{\prime} / P\right)}
$$


dengan :

$$
\begin{aligned}
& C_{N}= \text { Nilai koreksi overburden } \\
& p_{O},= \text { Tekanan } \text { overburden efektif } \\
&\left(\text { ton } / \mathrm{m}^{2}\right) \\
& p_{r}= \text { Tegangan efektif referensi } \\
&= 10 \text { ton } / \mathrm{m}^{2}, \\
& \mathrm{~N}=C_{N} . \mathrm{N}
\end{aligned}
$$

b. Koreksi pada tanah tanah pasir sangat halus atau pasir berlanau yang terendam air, Jika nilai $\mathrm{N}$ lebih besar dari 15, maka nilai $\mathrm{N}$ harus direduksi/dikoreksi menjadi N' dengan persamaan:

$$
\mathrm{N} 1^{\prime}=15+1 / 2\left(\mathrm{~N}^{\prime}-15\right)
$$

Untuk menghitung kapasitas dukung tiang pancang peneliti menggunakan beberapa persamaan antara lain:

a. Tahanan ujung ultimit

Tahanan ujung ultimit berdasarkan persamaan Mayerhoff dalam Hardiyatmo C.H, (2017)

$$
\mathrm{Qb}=40 \mathrm{Nr} \cdot \mathrm{Ap}_{\mathrm{p}}
$$

dengan:

$$
\begin{aligned}
\mathrm{Qb} & =\text { Tahanan ujung tiang } \\
\mathrm{Nr} & =\text { Nilai "N" rata-rata } 4 \mathrm{D} \text { keatas } \\
& \text { dan D kebawah } \\
\mathrm{Ap} & =\text { Luas penampang tiang pancang }
\end{aligned}
$$$$
\text { Tahanan ujung ultimit }
$$

berdasarkan persamaan Coyle dan

Castello dalam Hardiyatmo C.H, (2017)

$\mathrm{Qb}=\mathrm{Ap} . \mathrm{fb}$

dengan:

$\mathrm{Fb} \quad=$ Tahanan ujung satuan

Tahanan ujung ultimit berdasarkan persamaan US Army dalam Hardiyatmo C.H, (2017)

$$
\mathrm{Qb}=\mathrm{Ap} \cdot \mathrm{Pb} \cdot \mathrm{Nq}
$$

dengan:

$\mathrm{Pb}^{\prime}=$ Tahanan ujung satuan

$\mathrm{N}_{\mathrm{q}}=$ Faktor kapasitas dukung b. Tahanan Gesek Tiang

Tahanan gesek tiang berdasarkan persamaan Mayerhoff dalam Hardiyatmo C.H, (2017)

$$
\begin{aligned}
& \mathrm{Q}_{\mathrm{s}}=\left(\mathrm{A}_{\mathrm{s}} \cdot \mathrm{N}_{\mathrm{k}}\right) / 5 \\
& \mathrm{~A}_{\mathrm{S}}=\mathrm{A}_{\mathrm{k}} \cdot \mathrm{L}_{\mathrm{i}}
\end{aligned}
$$

dengan :

$\mathrm{Q}_{\mathrm{s}}=$ Tahanan gesek tiang

$\mathrm{A}_{\mathrm{s}}=$ Luas permukaan

$\mathrm{N}_{\mathrm{k}}=$ Nilai $\mathrm{N}$ rata-rata sepanjang tiang yang tertanam.

$\mathrm{A}_{\mathrm{k}}=$ Keliling tiang pancang

$\mathrm{L}_{\mathrm{i}} \quad$ = Panjang tiang yang tertanam didalam tanah

Tahanan gesek tiang berdasarkan persamaan Tomlinson dalam Hardiyatmo C.H, (2017)

Untuk tanah non kohesif

$\mathrm{Q}_{\mathrm{s}}=\sum \mathrm{A}_{\mathrm{s}} \mathrm{K}_{\mathrm{d}} \cdot \operatorname{tg} \delta . \mathrm{P}_{\mathrm{o}}$

dengan:

$$
\begin{aligned}
\mathrm{K}_{\mathrm{d}}= & \begin{array}{l}
\text { Koefisien tekanan tanah yang } \\
\text { bergantung pada kondisi tanah }
\end{array} \\
\delta= & \varphi_{\mathrm{d}}{ }^{\prime}=\text { Sudut gesek dinding } \\
& \text { efektif antara dinding tiang dan } \\
& \text { tanah } \\
\mathrm{P}_{\mathrm{o}}= & \text { Tekanan vertikal efektif rerata } \\
& \text { di sepanjang tiang yang } \\
& \text { besarnya sama dengan tekanan } \\
& \text { overburden efektif untuk } \mathrm{z} \leq \mathrm{z}_{\mathrm{c}}, \\
& \text { dan sama dengan tekanan } \\
& \text { vertikal kritis untuk } \mathrm{z} \geq \mathrm{zc}_{\mathrm{c}}
\end{aligned}
$$

Untuk tanah kohesif

$$
\mathrm{Q}_{\mathrm{s}}=\sum \mathrm{A}_{\mathrm{s}} \cdot \alpha \cdot \mathrm{Cu}
$$

dengan:

$\alpha=$ Faktor adhesi

$\mathrm{C}_{\mathrm{u}}=$ Kohesi

c. Kapasitas Dukung Ultimit Tiang

$$
\mathrm{Qu}=\mathrm{Qp}_{\mathrm{p}}+\mathrm{Q}_{\mathrm{s}}-\mathrm{W}_{\mathrm{p}}
$$

d. Kapasitas ijin tiang

$$
\mathrm{Qa}=\mathrm{Qu} / 3
$$


dengan:

$\mathrm{Q}_{\mathrm{a}} \quad=$ Kapasitas ijin tiang

$\mathrm{Qu}=$ Kapasitas dukung ultimit tiang

$3=$ Faktor aman

e. Kapasitas dukung ijin kelompok tiang

$$
\mathrm{Q}_{\mathrm{g}}=\mathrm{Qa} \cdot \mathrm{n} . \mathrm{Eg}
$$

f. Stabilitas Abutment

1) Stabilitas terhadap guling

Faktor keamanan digunakan untuk memastikan keamanan suatu struktur terhadap penggulingan $\left(F S_{\text {overtuning }}\right)>1,5$ dimana:

$$
F S_{\text {overtuning }}=\frac{\sum M}{\sum M}>1,5
$$

dengan :

$$
\begin{aligned}
& \Sigma \mathrm{Mg}=\text { Total momen yang dapat } \\
& F S_{\text {sliding }}=\frac{\sum V}{\sum H}>1,5
\end{aligned}
$$

3) Stabilitas terhadap daya dukung tanah

Faktor keamanan untuk memastikan keamanan struktur terhadap daya dukung tanah

$F S_{\text {bearing capacity }}$ adalah

$$
F S_{\text {bearing capacity }}=\frac{q}{q}>3
$$

\section{HASIL DAN PEMBAHASAN}

\section{Gambar dan Ukuran Abutment}

Ukuran Abutment yang telah di kerjakan pada pekerjaan pembangunan jembatan sei. Busuk adalah sebagai berikut:
a. Lebar (B)
: $4,0 \mathrm{~m}$
b. Panjang (L)
: $10,6 \mathrm{~m}$
c. Muka air tanah
: $0,5 \mathrm{~m}$
d. Dasar abutment
: $2,18 \mathrm{~m}$
e. Diameter tiang pancang : $0,5 \mathrm{~m}$
f. Panjang tiang pancang : $24 \mathrm{~m}$
g. Jenis tiang pancang : Beton pracetak
h. Rv dari bangunan atas : 227,94 t
i. Rh dari bangunan atas : $64,93 \mathrm{t}$

\section{Data Tanah dan Data Hasil Borlog} Hasil pengujian pengeboran dengan alat bor mesin berupa deskripsi tanah secara visual menurut kedalaman lobang bor, berupa diskripsi tanah menurut kedalaman serta data tanah beerdasarkan hasil laboratorium

\section{Perhitungan Kapasitas Dukung}

Untuk menghitung kapasitas dukung tiang pancang dari nilai " $\mathrm{N}$ " hasil pengujian standard penetration test (SPT) dengan persamaan sebagai berikut :

a. Tahanan Ujung Ultimit

$$
\text { Tahanan ujung ultimit }
$$
berdasarkan mayerhoff persamaan (4)

$$
\begin{aligned}
\mathrm{Qb} & =40 \mathrm{Nr} \cdot \mathrm{A}_{\mathrm{p}} \\
\mathrm{N}_{\mathrm{r}} & =19,59 \\
\mathrm{~A}_{\mathrm{p}} & =1 / 4 \times \pi \times 0,5^{2} \\
& =0,196 \mathrm{~m} \\
\mathrm{Qb} & =53,55 \text { ton }
\end{aligned}
$$

Tahanan ujung ultimit berdasarkan persamaan Coyle dan 
Castello, untuk memperoleh nilai tahanan ujung dapat mempergunakan grafik pada gambar 3, Untuk sudut gesek $\left(\varphi^{\prime}\right) 35^{\circ}, \mathrm{L} / \mathrm{d}=24 / 0,5=48$ maka tahanan ujung $\mathrm{fb}=850$ ton (pers 5 )

$$
\begin{aligned}
\mathrm{Qb} & =A \text { p.fb } \\
& =166,6 \text { ton }
\end{aligned}
$$

Tahanan ujung ultimit berdasarkan US Army persamaan 6, untuk memperoleh nilai tahanan ujung dapat mempergunakan grafik pada gambar 3. Untuk sudut gesek $\left(\varphi^{\prime}\right) 35^{\circ}$, berdasarkan gambar 4 diperoleh nilai $\mathrm{Nq}=65$

$$
\begin{aligned}
\mathrm{Qb} & =A p \cdot \mathrm{Pb} \cdot \mathrm{Nq} \\
& =166,51 \text { ton }
\end{aligned}
$$

Dari ketiga rumus di atas maka diperoleh:

$\mathrm{Qb}$ rata-rata $=162,22$ ton

b. Tahanan Gesek Tiang

Tahanan gesek tiang berdasarkan Mayerhoff persamaan 7 dan 8

$$
\begin{aligned}
\mathrm{A}_{\mathrm{s}} & =37,70 \\
\mathrm{~N}_{\mathrm{k}} & =10,34 \\
\mathrm{Q}_{\mathrm{s}} & =(37,70 \mathrm{x} 10,34) / 5 \\
& =77,96 \text { ton }
\end{aligned}
$$

Tahanan gesek tiang berdasarkan persamaan Tomlinson untuk tanah tidak berkohesi (persamaan 9)

$$
\begin{aligned}
\mathrm{Q}_{\mathrm{s}} & =\Sigma \mathrm{A}_{\mathrm{s}} \mathrm{K}_{\mathrm{d}} \cdot \operatorname{tg} \delta \cdot \mathrm{P}_{\mathrm{o}} \\
& =27,38 \text { ton }
\end{aligned}
$$

Tahanan gesek untuk tanah berkohesi (persamaan 10)

$$
\begin{aligned}
\mathrm{Q}_{\mathrm{s}} & =\sum \mathrm{A}_{\mathrm{s} .} \mathrm{C}_{\mathrm{u} \cdot} \cdot \alpha \\
& =88,27 \text { ton }
\end{aligned}
$$

Dari kedua rumus tahanan gesek di atas maka diperoleh:

$\mathrm{Q}_{\mathrm{s}}$ rata-rata $=96,80$ ton c. Kapasitas Dukung Ultimit Tiang Dari persamaan 11 diperoleh nilai kapasitas dukung ultimit sebesar :

$$
\begin{aligned}
\mathrm{Qu}_{\mathrm{u}} & =\mathrm{Qp}+\mathrm{Qs}_{\mathrm{s}}-\mathrm{W}_{\mathrm{p}} \\
\mathrm{W}_{\mathrm{p}} & =\frac{\pi(0,5)^{2}}{4} \times 24 \times 2,34 \\
& =22,06 \text { ton } \\
\mathrm{Qu} & =162,22+96,80-22,06 \\
& =236,96 \text { ton }
\end{aligned}
$$

d. Kapasitas ijin tiang Dengan menggunakan faktor aman $\mathrm{F}=3$ diperoleh kapasitas ijin tiang:

$$
\mathrm{Q}_{\mathrm{a}}=\frac{Q_{u}}{3}=78,97 \text { ton }
$$

e. Kapasitas tarik ijin tiang

Dengan mengambil faktor aman $\mathrm{F}=$ 3 diperoleh kapasitas tarik ijin tiang

$$
\mathrm{Q}_{\mathrm{tr}}=\frac{\left(Q_{S}+W_{P}\right)}{F}=39,62 \text { ton }
$$

f. Kapasitas dukung ijin kelompok tiang

$$
\begin{aligned}
\mathrm{Q}_{\mathrm{g}} & =\mathrm{Q}_{\text {tr }} \times \mathrm{n} \times \mathrm{Eg} \\
& =39,62 \times 18 \times 1 \\
& =713,16 \text { ton }
\end{aligned}
$$

\section{Gaya yang Bekerja pada Abutment} Gaya yang bekerja pada abutment adalah sebagai berikut:

1. Gaya Vertikal

Gaya vertikal terdiri dari beban beban struktur dan beban tanah di peroleh

$$
\begin{aligned}
& \mathrm{R}_{\mathrm{v}}=575,38 \text { ton } \\
& \mathrm{M}_{\mathrm{v}}=1160, \text { ton.m }
\end{aligned}
$$

\section{Gaya Harizontal}

Gaya horizontal yang terjadi akibat tekanan tanah yang terjadi pada abutment jembatan. Stabilitas abutment digunakan cara rankine dengan perhitungan pada tabel 2 dan 3 
Tabel 2 Momen Akibat Pa Terhadap Titik Tinjau O

\begin{tabular}{cccc}
\hline No & $\begin{array}{c}\text { Tekanan Tanah } \\
\text { Aktif }(\mathrm{Pa}) \\
\text { ( ton })\end{array}$ & $\begin{array}{c}\text { Jarak dari O } \\
(\mathrm{m})\end{array}$ & $\begin{array}{c}\text { Momen ke O } \\
\text { ( ton.m })\end{array}$ \\
\hline 1 & 59,82 & 3,84 & 229,71 \\
2 & 46,52 & 0,84 & 39,08 \\
3 & 9,04 & 0,56 & 5,06 \\
4 & 17,81 & 0,56 & 9,97 \\
$\mathrm{H}$ & 64,93 & 3,87 & 251,28 \\
$\Sigma \mathrm{Pa}$ & 198,12 & $\Sigma \mathrm{M}$ & 535,1 \\
\hline
\end{tabular}

Tabel 3 Momen Akibat Pp Terhadap Titik Tinjau O

\begin{tabular}{|c|c|c|c|}
\hline No & $\begin{array}{c}\text { Tekanan Tanah } \\
\text { Pasif (Pp) (ton) }\end{array}$ & $\begin{array}{c}\text { Jarak dari O } \\
(\mathrm{m})\end{array}$ & $\begin{array}{c}\text { Momen ke O } \\
\text { (ton.m) }\end{array}$ \\
\hline 1 & $-6,17$ & 1,93 & $-11,91$ \\
\hline 2 & $-41,44$ & 0,84 & $-34,81$ \\
\hline 3 & $-69,61$ & 0,56 & $-38,98$ \\
\hline 4 & $-17,81$ & 0,56 & $-9,97$ \\
\hline$\Sigma \mathrm{Pp}$ & $-86,87$ & $\Sigma \mathrm{M}$ & $-95,67$ \\
\hline
\end{tabular}

$\mathrm{P}_{\mathrm{h}}=198,12-86,87=111,25$ ton

$\sum \mathrm{M}_{\mathrm{h}}=535,1-95,67=439,43$ ton $\cdot \mathrm{m}$

\section{Stabilitas Abutment}

Berdasarkan hasil analisis dari data yang diperoleh maka Stabilitas Abutment adalah sebagai berikut:

a. Stabilitas Terhadap Penggeseran

Tahanan geser pada dinding sepanjang $\mathrm{B}=4,0 \mathrm{~m}$, dihitung dengan menganggap dasar dinding sangat kasar, sehingga sudut gesek $\delta_{b}=\varphi$ dan adhesi $c_{\mathrm{d}}=\mathrm{c}$. Untuk tanah $\varphi>0$ dan $c>0$ maka digunakan persamaan 15

$$
\begin{aligned}
\mathrm{Rh} & =c_{a} B+\sum V \cdot \operatorname{tg} \delta_{b} \\
& =(0 \times 4)+\left(575,38 \times \operatorname{tg} 28^{0}\right) \\
& =305,93 \text { ton } / \mathrm{m} \\
\mathrm{F}_{\mathrm{gs}} & =\frac{\sum R_{h}}{\sum P_{h}}=\frac{305,93}{111,25}=2,75>1,5
\end{aligned}
$$

b. Stabilitas terhadap penggulingan

Berdasarkan persamaan 14, maka stabilitas terhadap guling diperoleh nilai :

$$
\mathrm{F}_{\mathrm{gl}}=\frac{\sum M_{v}}{\sum M_{h}}=\frac{1.1,7}{4,4}=2,64>1,5
$$

c. Stabilitas terhadap keruntuhan kapasitas dukung tanah

Dalam hal ini akan digunakan persamaan Hansen dalam Hardiyatmo C.H, (2017). Pada hitungan dianggap fondasi terletak dipermukaan.

$$
\begin{aligned}
\text { xe } & =\frac{\sum M_{v}-\sum M_{h}}{\sum V} \\
& =\frac{1.160,75-439,43}{575,38}=1,25 \mathrm{~m}
\end{aligned}
$$

Lebar efektif :

$\mathrm{e}=\mathrm{B} / 2-\mathrm{xe}=4 / 2-1,25=0,75 \mathrm{~m}$

$>\mathrm{B} / 6=4 / 6=0,66 \mathrm{~m}$

$\mathrm{B}^{\prime}=\mathrm{B}-2 \mathrm{e}=4-(2 \mathrm{x} 0,75)=2,5 \mathrm{~m}$

Panjang efektif :

$\mathrm{e}=\mathrm{L} / 2-\mathrm{xe}=10,6 / 2-1,25=4,05$

$\mathrm{m}>\mathrm{L} / 6=10,6 / 6=1.77 \mathrm{~m}$

$\mathrm{L}^{\prime}=\mathrm{L}-2 \mathrm{e}=10,6-(2 \mathrm{x} 4,05)$

$$
=2,5 \mathrm{~m}
$$


Yasin, M., Yanti, G., Megasari, S,W,. / Analisis Abutment Jembatan Sei/ pp. 52 - 62

Bila dihitung dengan berdasarkan lebar fondasi efektif, yaitu tekanan fondasi ke tanah dasar terbagi rata secara sama maka :

$$
\begin{aligned}
\mathrm{q}^{\prime} & =\frac{V}{B^{\prime} \times L^{\prime}}=\frac{5,3}{2,5 \times 2,5} \\
& =92,06 \mathrm{ton} / \mathrm{m}^{2}
\end{aligned}
$$

Faktor aman terhadap keruntuhan kapasitas dukung :

$$
\mathrm{F}=\frac{\mathrm{Q}_{\mathrm{g}}}{\mathrm{q}^{\prime}}=\frac{713,16}{92,06}=7,74>3
$$

\section{E. KESIMPULAN}

Kesimpulan yang didapat dari penelitian ini adalah bahwa bangunan Abutment jembatan aman terhadap geser, guling dan keruntuhan kapasitas dukung tanah, dengan dibuktikan nilai safety factor Geser sebesar 2,75 > 1,5 dan Guling sebesar 2,64 > 1,5 serta keruntuhan kapasitas dukung tanah $7,74>3$.

\section{DAFTAR PUSTAKA}

Badan Standar Nasional, 2016, Pembebanan Untuk Jembatan, RSNI 1725-2016. Jakarta BSN.

Chandra A., Yanti G., Megasari SW., 2018 Analisis Daya Dukung
Pondasi Bored Pile pada Proyek Pembangunan Menara Listrik Transmisi $500 \mathrm{KV}$ PeranapPerawang, Jurnal Teknik, Vol 12, No 2, pp $171-178$

Hardiyatmo C.H., 2017, Analisis dan Perancangan Pondasi I, Gajah Mada University press, Yogyakarta.

Hardiyatmo C.H., 2015, Analisis dan Perancangan Pondasi II, Gajah Mada University press, Yogyakarta.

Hardiyatmo C.H., 2014, Mekanika Tanah II, Gajah Mada University press,

Husnah H., (2015). Analisa Daya Dukung Pondasi Tiang Pancang Pada Proyek Pembangunan Pondasi Tissue Block 5 \& 6. SIKLUS: Jurnal Teknik Sipil, 1(1), 15 - 25. https://doi.org/10.31849/siklus.v1i $\underline{1.125}$

Supriyadi dan Muntohar. 2007, Jembatan, Beta Offset, Yogyakarta. 